\title{
Procaryotic infections in the mussel Mytilus galloprovinciallis and in its parasite the turbellarian Urastoma cyprinae
}

\author{
Michel Comps ${ }^{1, *}$, Gilbert Tigé ${ }^{2}$ \\ ${ }^{1}$ IFREMER, Chemin de Maguelone, 34250 Palavas-les-Flots, France \\ ${ }^{2}$ IFREMER, 12 rue des Résistants, 56470 La Trinité-sur-Mer, France
}

\begin{abstract}
Mussels Mytilus gailoprovincialis from the Thau lagoon (Mediterranean coast of France) were regularly sampled to determine the prevalence and intensity of parasitic infections. Microscopically, hepatopancreatic tubules of the mussel appeared infected by a rickettsia-like organism (RLO). Each RLO were surrounded by 2 unit membranes, and colonies composed of several bacteria were enclosed within a vacuolar membrane of the host cell. In addition, examination by transmission electron microscopy revealed that the RLO was infected by phage particles. Histological investigations of the turbellarian Urastoma cyprinae parasitizing the mussels have shown that this ectoparasite was also infected by 2 types of procaryotes, a chlamydia-like organism (CLO) and a mollicute-like organism (MLO). The CLO displayed characteristic developmental stages of the Chlamydiales and was secondarily infected by electron-dense particles presumed to be phage particles. The MLO exhibited some morphological characteristics of the mollicutes, in that the microorganisms were bounded by a single membrane sharing a trilaminar structure. Neither of these microorganisms have previously been reported in Platyhelminthes.
\end{abstract}

KEY WORDS: Mytilus galloprovincialis · Turbellarian Urastoma cyprinae - Rickettsiales · Chlamydiales Mollicutes Phage infection

\section{INTRODUCTION}

Although no important diseases have affected the mussel industry in the Thau lagoon (French Mediterranean coast) during the past decade, a routine survey to check for growth and mortality is regularly performed. Two years of sampling Mytilus galloprovincialis has shown that this mollusc serves as the host for several endemic parasites, particularly Mytilicola intestinalis (Steuer 1902), Marteilia maurini (Comps et al. 1982) and Urastoma cyprinae (von Graff 1913). In addition, during the survey histological examinations revealed procaryotic infections within the digestive gland of both mussel specimens and in the digestive tract of $U$. cyprinae.

We report here the morphological features of the procaryotes found in the mussel Mytilus galloprovin-

•E-mail: michel.comps@ifremer.fr cialis and in its ectoparasite, the turbellarian Urastoma cyprinae. More extensive field studies are currently underway to better identify these microorganisms.

\section{MATERIALS AND METHODS}

Morphological characterization of the procaryotes was made from naturally infected mussels parasitized by the turbellarian, Urastoma cyprinae. For light microscopy studies, specimens were fixed in Davidson fixative (Shaw \& Battle 1957) for $2 \mathrm{~h}$. Sections were stained by the Mann-Dominici method (Gabe 1968). For transmission electron microscopy, tissues were fixed overnight at $4^{\circ} \mathrm{C}$ in $2.5 \%$ glutaraldehyde buffered with $0.4 \mathrm{M}$ sodium cacodylate $(\mathrm{pH} 7.2)$, postfixed at room temperature in $1 \% \mathrm{OsO} 4$ and embedded in Epon resin. Sections were contrasted with saturated uranyl acetate in $50 \%$ ethanol, followed by lead citrate (Reynolds 1963). 


\section{RESULTS}

\section{RLO-infection in the mussel}

Light microscopy

Extensive examinations of mussel digestive tracts revealed inclusion bodies (ib) within the cytoplasm of digestive cells (Fig, 1a). In semi-thin sections, ibs 4 to $10 \mu \mathrm{m}$ in diameter appeared granular and exhibited different degrees of basophilia.

\section{Electron microscopy}

Ibs consisted of membrane-bound microcolonies of microorganisms with a procaryotic morphology (Fig. 1b) Typically, only 1 ib was found within infected cells; however, multiple ibs were also detected in some cases (Fig. 1c). The microorganisms were rod-shaped, about 500 to $800 \mathrm{~nm}$ long and $400 \mathrm{~nm}$ in diameter, and surrounded by an envelope which consisted of 2 trilaminar membranes. Their cytoplasm was electrondense at the periphery while the center was reticulate.

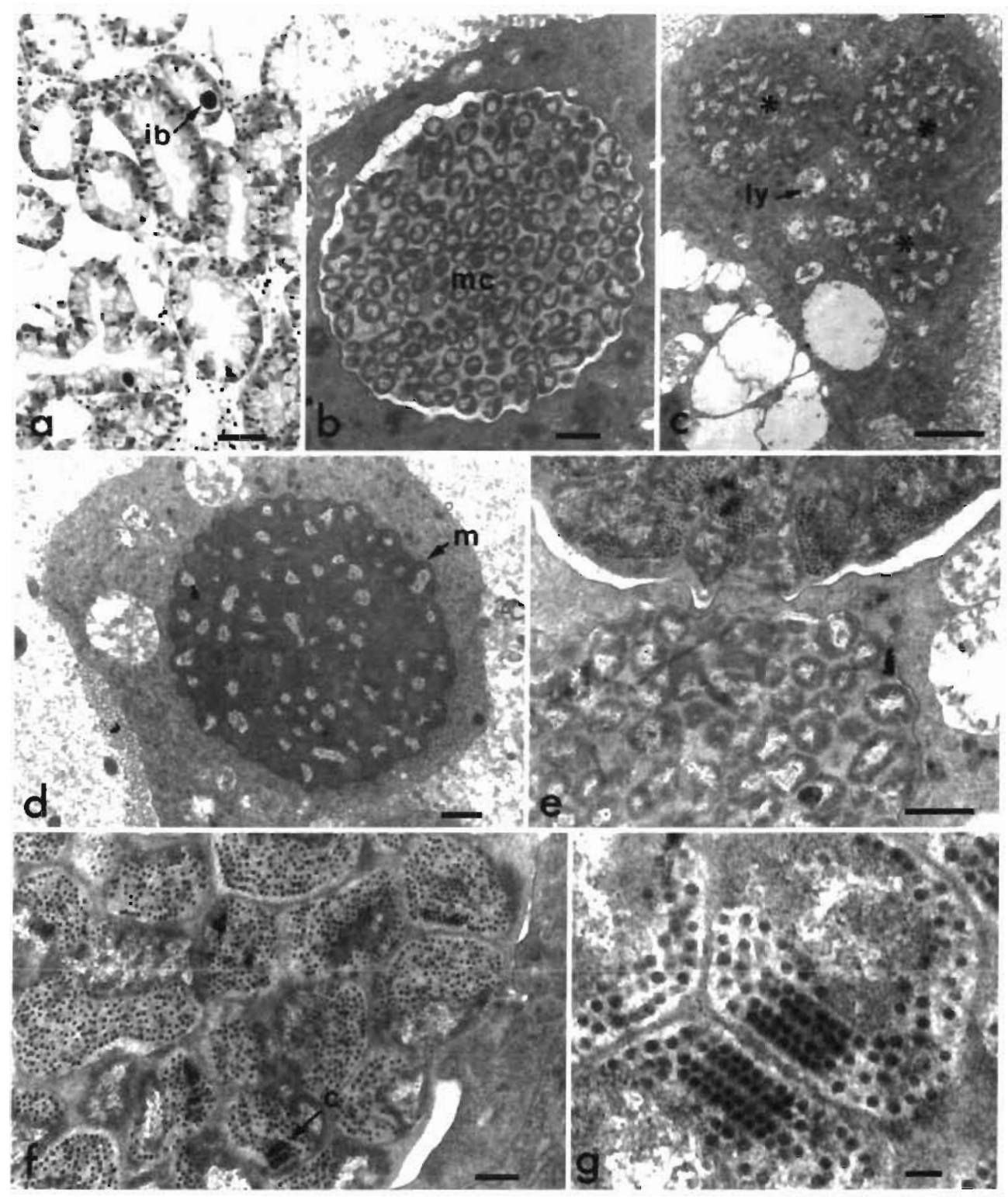

Fig. 1. Morphology of the rickettsia-like organism (RLO) infecting Mytilus galloprovincialis. (a) Section through the digestive diverticula displaying basophilic inclusion bodies (ib) localized within the tubule epithelium. Hematoxylin-eosin. Scale bar $=$ $50 \mu \mathrm{m}$. (b) Electron micrograph of an ib: RLOs exhibit a characteristic swollen outer membrane; the center of the cells is occupied by finely reticulated dense fibers. mc: microcolony. Scale bar $=500 \mathrm{~nm}$. (c) Enlarged epithelial digestive cell containing $3 \mathrm{micro}-$ colonies of RLOs $(*)_{i}$ lysozomes (ly). TEM. Scale bar $=2 \mu \mathrm{m}$. (d) In some parasitic vacuoles, the RLOs are found within electrondense material; the membrane $(\mathrm{m})$ of the vacuole appears to consist of a single thick layer; TEM. Scale bar $=500 \mathrm{~nm}$. (e) Digestive cell containing microcolonies of phage-infected and uninfected RLOs; note the size difference of the 2 types of RLOs. TEM. Scale bar $=500 \mathrm{~nm}$. (f) RLOs with severe phage infections; phage particules are dispersed throughout the cells or arranged in paracrystalline arrays (c). TEM. Scale bar $=200 \mathrm{~nm}$. (g) Detail of paracrystalline arrays of phage particules. TEM. Scale bar $=100 \mathrm{~nm}$ 
Some bacteria were undergoing binary fission. In some ibs, the microorganisms were observed within finely granular and electron-dense material (Fig. 1d). Other ibs consisted of greatly distended microorganisms containing electron-dense phages (Fig. 1e). These particles were icosahedral and had a diameter of about $45 \mathrm{~nm}$ and appeared randomly scattered through the cytoplasm or formed paracrystalline arrays (Fig. 1f,g).

\section{Procaryotic infections in the turbellarian parasite of the mussel}

Light microscopy

Sections of the turbellarian parasitizing the gills of the mussels displayed similar ibs localized among the sub-tegumentary glands. Larger in size (15 to $35 \mu \mathrm{m}$ ) than the ibs found in the mussels, these bodies were less basophilic (Fig. 2a).

\section{Electron microscopy}

In the worm Urastoma cyprinae, 2 types of microorganisms were observed within sub-tegumentary cells, a chlamydia-like organism (CLO) and a mycoplasma-like organism (MLO).

The CLO displayed the main developmental stages that occur during the life cycle of the Chlamydiales. The reticulate bodies were ovoid, 450 to $600 \mathrm{~nm}$ in size, and capable of dividing (Fig. 2b,c). As in the mussel, the bacteria were often tightly packed and included in dense material (Fig. 2d). The ibs exhibited central condensation of the fibrillar material (Fig. 2e). The elementary bodies were pleomorphic and measured about 200 to $250 \mathrm{~nm}$ in diameter (Fig. 2f). They were bounded by a complex envelope consisting of 3 electron-dense layers separated by 2 intermediate electron-luscent layers (Fig. 2g). The nucleoid exhibited an irregular profile and its high electron density contrasted with the surrounding cytoplasm. In some micro-colonies of reticulate bodies, several elementary bodies were found within a membrane-bound vacuole (Fig. 2h).

In highly parasitized worms, numerous reticulate bodies appeared to contain virus-like particles (Fig. 3a). These particles, about $50 \mathrm{~nm}$ in diameter, were scattered throughout the cytoplasm or formed paracrystalline arrays which occupied wholly or partly the reticulate bodies (Fig. 3b). Morphologically, the particles appeared spherical or hexagonal in outline and each consisted of a dense core surrounded by a unit membrane-like envelope. Earlier stages showed incomplete particles which consisted of electron-dense material associated with the DNA fibrils. Maturing particles were also found dispersed throughout the parasitic vacuole, probably originating from lysed infected reticulate bodies (Fig. 3c).

Additionally, ultrastructurally in 1 CLO-infected $U_{r a-}$ stoma cyprinae, basophilic cells contained unusual polymorphic bodies exhibiting procaryotic structures. The more distinctive form was rod shaped, 150 to $400 \mathrm{~nm}$ long and $40 \mathrm{~nm}$ wide, while others were paraspherical or pear shaped (Fig. 4a). These particles were enclosed by a single membrane showing a trilaminar structure and their cytoplasm appeared finely granular and more or less electron-dense (Fig. 4b). Among the dense particles, ovoid bodies, 70 to $180 \mathrm{~nm}$ in size, displayed clear cytoplasm which contained structures analogous to ribosomes and DNA strands and median trilaminar elements (Fig. 4c).

\section{DISCUSSION}

Since the first report of a rickettsia-like infection in the marine mollusc Mya arenaria (Harshbarger et al. 1977), numerous procaryotes related to the Rickettsiales, Chlamydiales and to the Mycoplasmas have been described from various marine invertebrates. During the past several years, reviews have contributed to the knowledge base about these organisms (Laukner 1983, Fries \& Grant 1991, Chiou-Ming Wen et al. 1994). In the mussels, cases of infection by parasites belonging to these groups of organisms were reported in Mytilus edulis and $M$. californianus from the United States by Yevich \& Barszcz (1980) and in $M$. edulis and $M$. galloprovincialis from Spain by Figueras \& Montes (1988), Figueras et al. (1991) and Robledo et al. (1994). Additionally, a CLO was identified by Cajaraville \& Angulo (1991) in $M$. edulis from the Basque coast. However, little information is presently available about such infections in marine worms since only 1, Neorickettsia helminthoeca, has been detected in the trematode Nanophyetus salmincola (Farrell et al. 1964). This rickettsia is a pathogen of canines (Millemann et al. 1964).

According to its morphological features and its replicative cycle by single binary fission, the procaryote found in the digestive cells of the mussel Mytilus galloprovincialis might be related to the order Rickettsiales. Based on its ability to produce membranebound cytoplasmic vacuoles in an invertebrate host, this microorganism could be considered closely related to the Wolbachiae. This is the first report of an RLO to be described in the mussel $M$. galloprovincialis; only CLOs have been previously reported in this species (Cajaraville \& Angulo 1991, Robledo et al. 1994). Previously, Figueras et al. (1991) identified Rickettsiae in 


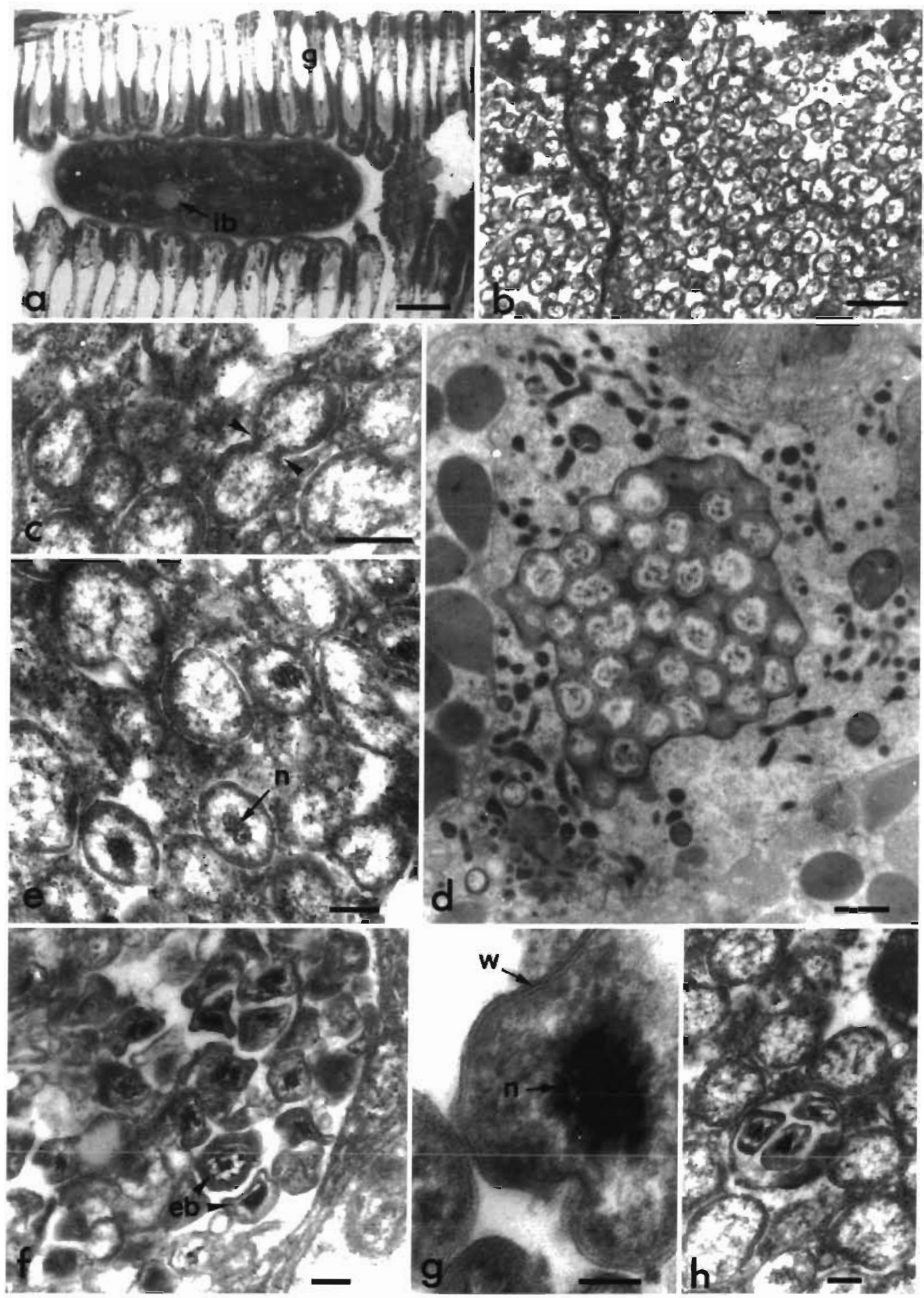

Fig. 2. Histology of the chlamydia-like organism (CLO) infection in Urastoma cyprinae. (a) Section showing the turbellarian localized in the gills $(\mathrm{g})$ of the mussel, inclusion body (ib). Toluidine blue. Scale bar $=50 \mu \mathrm{m}$. (b) CLO cytoplasmic inclusion found in the subtegumentary gland. TEM. Scale bar $=1 \mu \mathrm{m}$. (c) Reticulate body undergoing fission (arrowheads). TEM. Scale bar = $500 \mathrm{~nm}$. (d) Cytoplasmic inclusion containing paraspherical reticulate bodies within electron-dense material. TEM. Scale bar = $500 \mathrm{~nm}$. (e) Ibs characterized by the presence of a central electron-dense nucleoid (n). TEM. Scale bar = $200 \mathrm{~nm}$. (f) Microcolony of elementary bodies (eb). TEM. Scale bar $=200 \mathrm{~nm}$. (g) Electron micrograph of an eb displaying the fine structure of the wall (w); nucleoid $(\mathrm{n})$. Scale bar $=50 \mathrm{~nm}$. (h) Microcolony of reticulate bodies containing eb within a membrane-bound vacuole. TEM. 


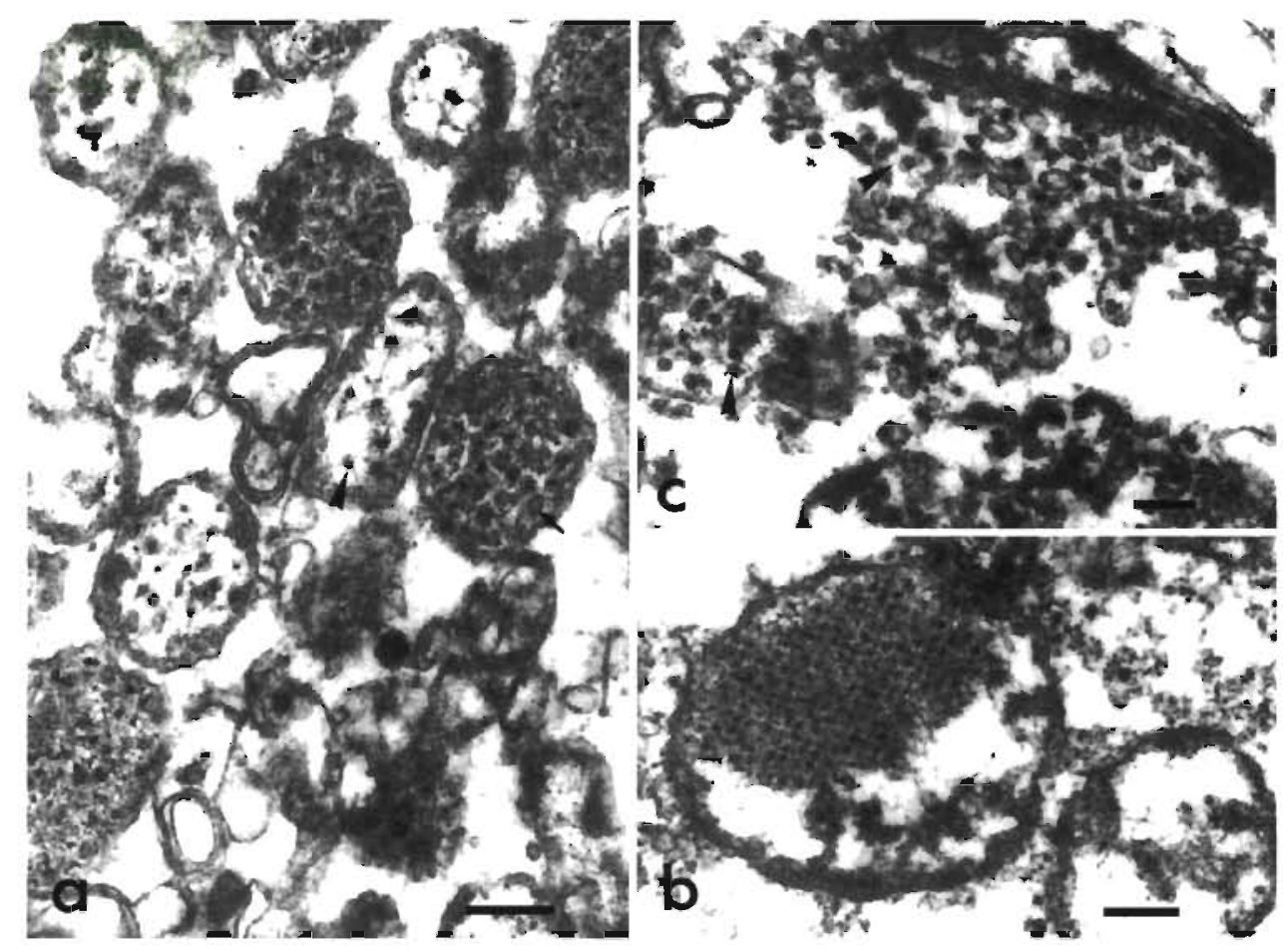

Fig. 3. Fine structure of phage-infected CLO. (a) Different stages of phage development are present in the same microcolony of procaryotes. First particules form among the DNA fibres in the central area of the CLO (arrowhead). Some CLOs are completely full of phage particles (arrow). TEM. Scale bar $=200 \mathrm{~nm}$. (b) Enlarged CLO containing numerous particles in regular arrangement. TEM. Scale bar $=200 \mathrm{~nm}$. (c) When the membrane of the microorganism is ruptured, phage particles (arrowheads) are scattered throughout the parasitic vacuole among cellular debris. TEM. Scale bar $=200 \mathrm{~nm}$

this mollusc through light microscopic examinations, but did not illustrate the developmental mode of the procaryote. Although the RLO-infected mussel cells exhibited some cytopathic effects, including hypertrophy and abnormal vacuolization of the cytoplasm, no characteristic histological changes were seen in the neighbouring cells of the digestive tubules. However, some changes in the structure of the parasitic vacuole, such as an increase in the density of its content or the thickening of its membrane, could correspond to host reactions. Apparently, spreading of the pathogen is also controlled by the phage, which can infect all the bacteria contained within a vacuole. Similar phage infections of procaryotes were reported in other molluscans such as Mercenaria mercenaria (Harshbarger et al. 1977), Tellina tenuis (Buchanan 1978), and in other invertebrates including the snail Bithynia siamensis goniomphalus (Adam et al. 1994) and the scorpion Buthus occitanus (Morel et al. 1974).

The CLO found in Urastoma cyprinae is the first infectious agent described in this species. It exhibits some similarities with the Chlamydiales reported in marine invertebrates (Harshbarger et al. 1977, Comps \& Deltreil 1979, Joly \& Comps 1980, Cajaraville \& Angulo 1991), but differs in the morphology of its ele- mentary bodies. To date, none of these organisms have been classified in the order Chlamydiales and their relationship to their hosts is obscure. Concerning the parasite of $U$. cyprinae, although the sampled worms demonstrated $80 \%$ infection prevalence, we were unable to determine what effect, if any, this parasite has on its host. CLO development and its potential pathogenic effect on the worms may be seriously limited by the ability of the infecting phage to destroy this microorganism.

According to its morphological characteristics (pleomorphic procaryotic cell delimited only by a plasma membrane), the second intracellular microorganism found in Urastoma cyprinae appears closely related to the Mollicutes (Razin \& Freundt 1983), but phenotypic characters alone were not sufficient to determine its specific placement. Few organisms belonging to this group have been reported in marine invertebrates. Harshbarger et al. (1977) first reported a mycoplasmalike organism within the gut cells of the American oyster Crassostrea virginica. Later, a new type of mycoplasma was described by Krol et al. (1991) in the hepatopancreatic cells of Litopenaeus vannamei.

The observation of new intracytoplasmic procaryotes in marine invertebrates confirms that these animals, 


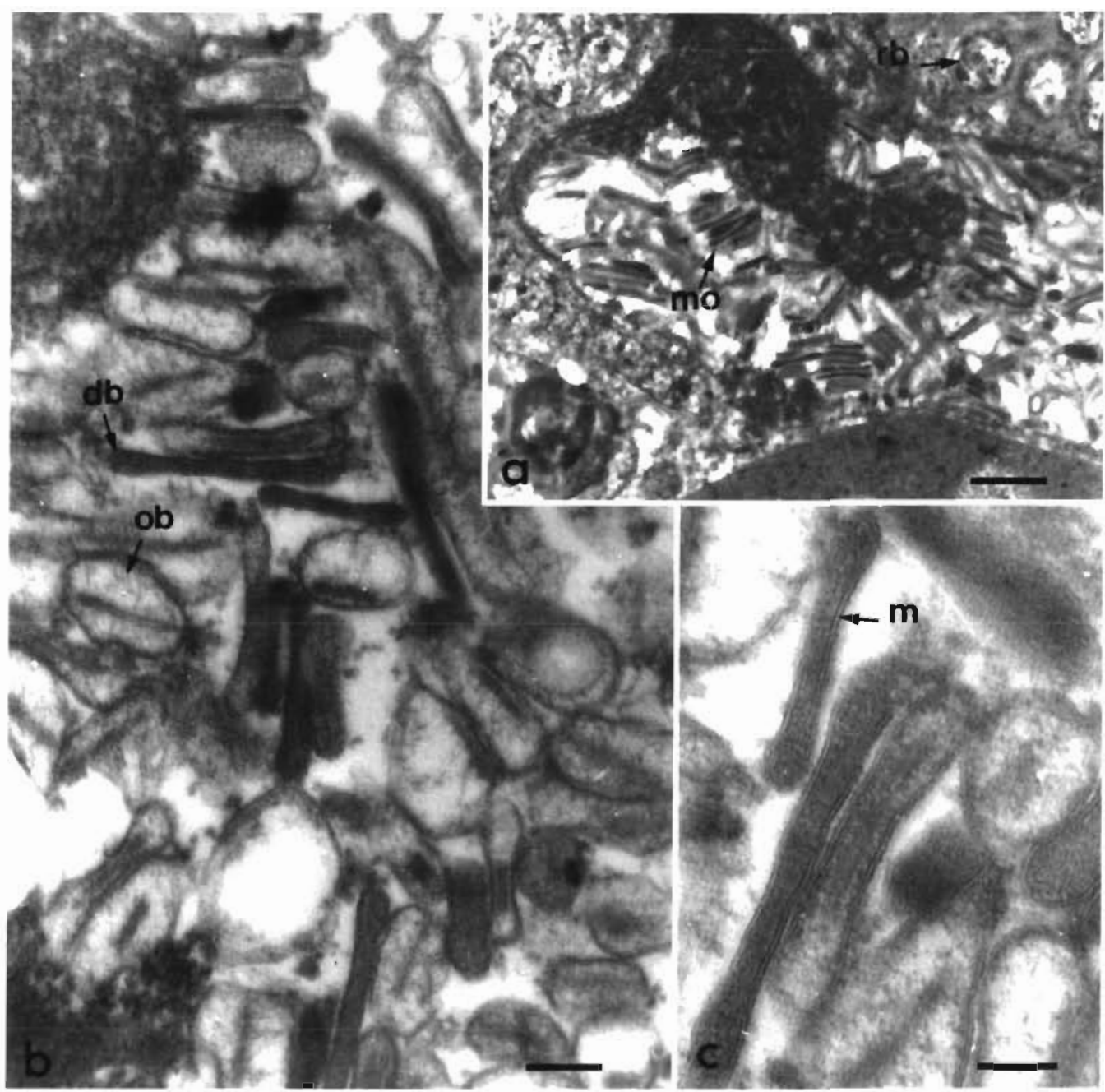

Fig. 4. Mycoplasma-like organism (MLO) from Urastoma cyprinae. (a) Electron micrograph of MLO-infected tissues (mo); reticulate body (rb) inside a CLO-infected cell. Scale bar $=500 \mathrm{~nm}$. (b) Two types of bodies are found in the MLO-containing cells: dense bodies $(d b)$ and ovoid bodies (ob). TEM. Scale bar $=100 \mathrm{~nm}$. (c) Higher magnification of dbs: finely granular, the cytoplasm is surrounded by a single membrane $(\mathrm{m})$. TEM. Scale bar $=50 \mathrm{~nm}$

particularly bivalves, are common hosts for these types of parasites. Generally, they cause mild cytopathic effects only in the infected cells. To date, no report of serious disease by these pathogens has been published, except in the scallop Pecten maximus. In this case, a rickettsia was suspected to have caused mortalities in scallop beds located in Brittany (France), but its role in the epizootic was not experimentally demonstrated (LeGall et al. 1988).

The pathogenicity and the transmission of these microorganisms remain in actual fact unknown and until now, were only the subject of various hypothesises (Fries \& Grant 1991, Renault \& Cochennec 1994). It is obvious that more experimental data is needed to determine the exact relationship between these microorganisms and their hosts.
Purification of the CLO present in the Turbellarian Urastoma cyprinae is being conducted to further characterize this microorganism and to attempt experimental transmission.

Acknowledgements. We thank D. Lightner from the University of Tucson, Arizona, for reviewing the manuscript. We also thank J. C. Harshbarger, The George Washington University Medical Center, Washington, DC, for suggestions.

\section{LITERATURE CITED}

Adam R, Pipitgool V, Sithithaworn P, Hinz E, Storch V (1994) Rickettsiales-like organisms in the digestive gland of Bithynia siamensis goniomphalus (Prosobranchia: Bithyniidae) infected with Opisthorchis viverrini (Trematoda: Digenea). J Invertebr Pathol 63:26-30 
Buchanan J (1978) Cytological studies on a new species of rickettsia found in association with phage in digestive gland of the marine bivalve mollusc, Tellina tenuis (da Costa). J Fish Dis 1:27-43

Cajaraville MP, Angulo E (1991) Chlamydia-like organisms in digestive and duct cells of mussels from the Basque coast. J Invertebr Pathol 58:381-386

Chiou-Ming Wen, Guang-Hsiung Kou, Shiu-Nan Chen (1994) Rickettsiaceae-like mocroorganisms in the gill and digestive gland of the hard clam, Meretrix lusoria Röding. J Invertebr Pathol 64:138-142

Comps M, Deltreil JP (1979) Un microorganisme de type rickettsien chez l'huitre portugaise Crassostrea angulata Lmk. C R Acad Sci Ser D 289:69-171

Comps M, Pichot Y, Papagianni P (1982) Recherches sur Marteilia maurinin. sp. parasite de la moule Mytilus galloprovincialis Lmk. Rev Trav Inst Pêches Marit 45:211-214

Farrell RK, Lloyd M, Earp B (1964) Persistence of Neorickettsia helminthoeca in endoparasite of the Pacific salmon. Science 145:162-163

Figueras AJ, Montes J (1988) Parasites and diseases of mussels (Mytilus edulis and M. galloprovinciallis) cultivated on rafts in Galicia (NW Spain). In: Perkins FO, Cheng TC (eds) Abstracts 3rd Int Colloq Pathol Mar Aquacul 1988, Gloucester Point, Virginia, p 95-96

Figueras AJ, Jardon CF, Caldas JR (1991) Diseases and parasites of rafted mussels (Mytilus galloprovincialis Lmk): preliminary results. Aquaculture 99:17-33

Fries CR, Grant DM (1991) Rickettsiae in gill epithelial cells of the hard clam, Merceneria mercenena. J Invertebr Pathol $57: 166-171$

Gabe M (1968) Techniques histologiques. Masson Edit., Paris

Harshbarger JC, Chang SC, Otto SV (1977) Chlamydiae (with phages), mycoplasmas and rickettiae in Chesapeake Bay bivalves. Science 196:666-668

Joly JP, Comps M (1980) Etude d'un microorganisme de type chlamydien chez la palourde Ruditapes decussatus L. Rev Trav Inst Pêches Marit 44(3):285-287

Krol RM, Hawkins WE, Overstreet RM (1991) Rickettsial and mollicute infections in hepathopancreatic cells of cultured pacific white shrimp (Penaeus vannamei). J Invertebr Pathol 57:362-370

Editorial responsibility: Albert Sparks,

Seattle, Washington, USA
Lauckner G (1983) Disease of Mollusca: Bivalvia. In: Kinne O (ed) Diseases of marine animals, Vol II, Introduction, Bivalvia to Scaphopoda. Biologische Anstalt Helgoland, Hamburg, p 630-632

Le Gall G, Chagot D, Mialhe E, Grizel H (1988) Branchial Rickettsiales-like infection associated with a mass mortality of sea scollop Pecten maximus. Dis Aquat Org 4:229-232

Millemann EH, Gebhardt GA, Knapp SE (1964) 'Salmon poisoning' disease. I. Infection in a dog from marine salmonids. J Parasitol 50:588-589

Morel G, Veyrunes JC, Vago C (1974) Infection virale chez la rickettsie du scorpion Buthus occitanus. CR Acad Sci 279 Ser D:1365-1367

Razin S, Freundt EA (1983) Class Mollicutes. In: Bergey's manual of systematic bacteriology, Vol 1 Williams \& Wilkins, Baltimore, MD, p 740-741

Renault $T$, Cochennec N (1994) Rickettsia-like organisms in the cytoplasm of gill epithelial cells of the Pacific oyster Crassostrea gigas. J Invertebr Pathol 64:160-162

Reynolds W (1963) The use of lead citrate at high $\mathrm{pH}$ as an electron-opaque stain in electron microscopy. J Cell Biol $17: 208-212$

Robledo JAF, Santarém MM, Figeras A (1994) Parasite loads of rafted blue mussels (Mytilus galloprovinciallis) in Spain with special reference to the copepod, Mytilicola intestinalis. Aquaculture 127:287-302

Shaw BL, Battle HI (1957) The gross and microscopic anatomy of the digestive tract of the oyster Crassostrea virginica (Gmelin). Can J Zool 35:325-347

Steuer A (1902) Mytilicola intestinalis n. gen. n. sp. aus dem Darme von Mytilus galloprovincialis Lam. Zool Anz 25 $635-637$

von Graff L (1913) Platyhelminthes. Turbellaria. II. Rhabdocoelida. In: Shulze FE (ed) Das Tierreich. Eine Zusammenstellung und Kennzeichnung der rezenten Tierformen. 35 Lieferung. Friedlander, Berlin

Yevich PP, Barszcz CA (1980) Histopathology as a monitor for marine pollution. Results of the histopathologic examination of animals collected for the U.S. 1976 watch program. Int. Counc Explor Sea, Special Meeting on Diseases of Commercially Important Marine Fish and Shellfish (Copenhagen, 1980), No. 56

Submitted: February 24, 1999; Accepted: August 17, 1999 Proofs received from author(s): November 19, 1999 